\title{
Emergy evaluation of a traditional farming system. Case study: Leh District (Ladakh - Indian Trans-Himalaya)
}

\author{
By Vladimiro Pelliciardi ${ }^{1}$, Leonardo Varvaro ${ }^{2}$, Federico Maria Pulselli ${ }^{3}$
}

\begin{abstract}
A b s t r a c t
Ladakh traditional farming system has been included on the F.A.O. list of possible "Globally Important Agricultural Heritage Systems", worthy of being preserved and conserved. The paper describes and assesses cultivation practices in a typical familymanaged farm, located in central Ladakh, analysing how natural resources are exploited, conserved and recycled. Emergy evaluation, an environmental accounting methodology, has been applied to evaluate and compare five staple crop productions: barley, wheat, pea, mustard, and fodder alfalfa. Unit Emergy Values of products (UEV, emergy per unit product, a measure of the environmental production cost) are calculated, taking into account the inputs to production such as water from glaciers, soil fertility, human and animal labour, and more. Results show that the traditional agricultural practices in Ladakh, completely supported by renewable flows, are efficient in the use of local resources. In fact, the UEVs of agroproducts are similar to those of analogous products of conventional agriculture (e.g. $5.27 \mathrm{E}+05$ and $6.64 \mathrm{E}+05 \mathrm{semj} / \mathrm{J}$ for barley and wheat in Ladakh, respectively; $7.37 \mathrm{E}+05 \mathrm{semj} / \mathrm{J}$ for corn in USA), though the inputs of Ladakh agriculture are strongly limited in type and quantity. At the same time, local farmers can create, maintain and rebuild soil functions whose UEV is $1.62 \mathrm{E}+07 \mathrm{semj} / \mathrm{J}$.
\end{abstract}

Keywords: Ladakh, agrosystem, emergy, environment, sustainability

\section{Introduction}

Ladakh is a region of Indian Trans-Himalaya (Figure 1), geographically classified as "high cold desert" (Negi, 2002) (altitude ranging from 2,300 to 7,672 m a.s.1.). Politically, it is a division of the Jammu and Kashmir State of India, and is divided into two districts: Leh in the central and eastern parts (area: 45,110 km²; 147,104 inhabitants), and Kargil (area:14,036 km²; 143,388 inhabitants), in the northwest. Both districts are governed by their respective Ladakh Autonomous Hill Development Councils. The population is dispersed in almost all the accessible areas, with the exception of the cities of Leh and Kargil. Settlements are typically located around the banks and terraces of major rivers and streams; the nomadic pastoralist communities live on the plateau up to 4,500 m.a.s.l.. For centuries this population, living in an area that is poor in natural resources, has led a relatively self-reliant existence, based upon subsistence agriculture and livestock husbandry, but also upon trading goods with Tibet, central Asia, and the Indian plain (Rizvi 1983).

${ }^{3}$ Department of Physical, Earth and Environmental Sciences, University of Siena, Italy. 


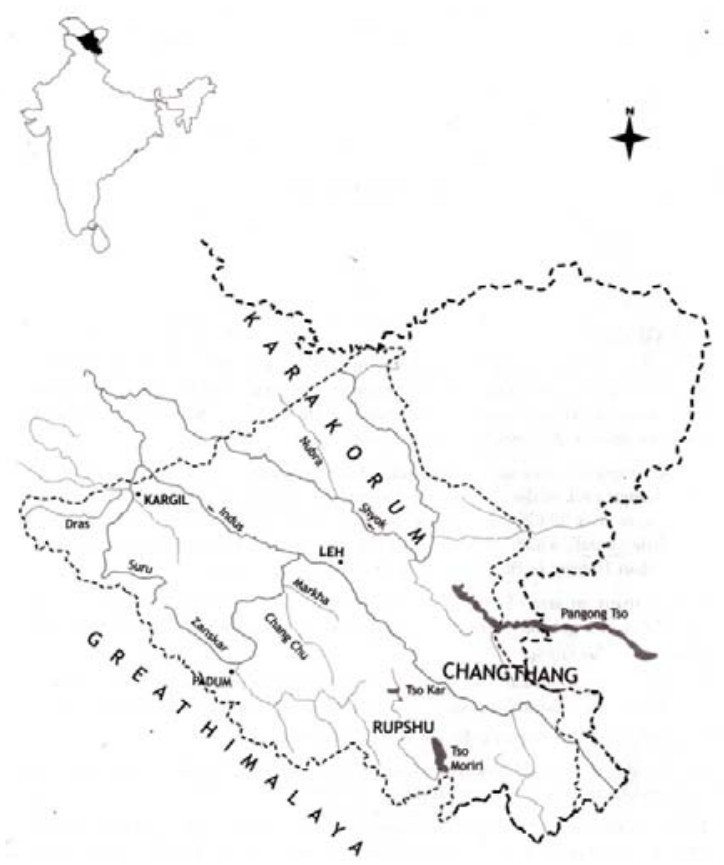

Figure 1. Ladakh (outlined) is located between the Great Himalaya and Karakorum ranges. Source: (Humbert-Droz \& Dawa 2004).

Agriculture still remains the backbone of every village economy, engaging up to $70 \%$ of the working force as cultivators, agricultural labourers and livestock breeders (LAHDCL, 2008). The FAO (2008) classifies Ladakhi agriculture among the possible "Globally Important Agricultural Heritage Systems", defined as "remarkable land use systems and landscapes which are rich in globally significant biological diversity evolving from the coadaptation of a community with its environment and its needs and aspirations for sustainable development". Local farmers have been able to create favourable farming conditions by channelling meltwater from glaciers, terracing the land, producing and preserving soil fertility, and implementing methods of fair resource share and collaboration among them. The main agricultural products are barley, wheat, millet, pulses and fruit, such as apricots and apples; large ruminants like yaks, dzos, cows, donkeys, horses, sheep and goats are reared for dairy products, meat, skin, etc., but also for transport or to power agriculture. Agricultural practices are fully integrated within ecosystem dynamics in an area characterized by well defined biophysical constraints and extreme climatic conditions. Overall, the traditional land-based economy is characterized by self-sufficiency. Sabharwal \& Singh (2005) noted that "Ladakhi farmers prepare their own manure, seeds and other agricultural inputs, rear their own animals and prepare their own farms in a well-integrated, coordinated and balanced form of agriculture that has evolved in response to agro-climatic conditions unique in India". The indigenous knowledge in the Himalayan region is handed on orally from parents to children. This process has been fundamental for the population in this area to operate and maintain its well-being for centuries. Verma et al. (1998) stated that it is "the inter-generational 
wisdom of local inhabitants to perform their livelihood operations in a most eco-friendly manner under remote, isolated and inaccessible conditions characterized by harsh climate and limited survival options". For other contributions on traditional ecological knowledge for indigenous ecosystem management, see Diemont \& Martin (2009), Alfaro-Arguello et al. (2010), and on Ladakh agriculture, see Singh (1992), Osmaston (1994), Mankelow (1999). Recently, the use of machineries, fossil energy and chemical fertilizers have become more common, under the pressure of modernization and economic growth, mostly near urban areas. These factors, together with the development of tourism (Pelliciardi, 2010), the tertiary sector, and urbanization, are influencing the behaviour of the local population.

This paper tries to acknowledge and define the relationship between ecosystem dynamics and the organization of farming practices; it also evaluates the ability of the system to convert few inputs into products in an efficient way, assuring population subsistence and preserving suitable conditions for food production to continue over time. The emergy evaluation, an environmental accounting methodology based on energy transformation in the biosphere (Odum, 1988, 1996), is applied to the most important local crop cultivations: barley (Hordeum vulgare L.), wheat (Triticum aestivum L.), pea (Pisum sativum L.), mustard (Brassica rapa ssp. campestris L.), and fodder Alfalfa (Medicago sativa L.). Emergy (Odum, 1988, 1996) is a thermodynamics-based method that measures the exchange of energy between ecosystems and human systems. It enables to express any kind of energy flow (wind energy, fossil fuels, electricity, etc.) in solar equivalent, i.e. the solar energy that has been used up, directly or indirectly, to obtain that flow. Emergy evaluation has been often applied to agricultural systems; for an overview, see Brandt-Williams (2002). More specifically, several authors have applied emergy evaluation to assess agriculture production processes in developing countries: Agostinho et al., 2008, Cavalett et al., 2006 and Haden, 2002, dealt with small family farms; Xi \& Qin, 2009, Lu. H. et al., 2009, Zhang et al., 2007, Cuadra \& Björklund, 2007, Martin et al., 2006, Comar et al., 2004 and Lefroy \& Rydberg, 2003, dealt with different scales and management of farming systems.

\section{Materials and Methods}

\subsection{The Traditional Farming System}

The Ladakh traditional farming system can be viewed as an ordered series of cyclical sequential operations: manuring, ploughing, sowing, levelling, channelling, irrigating, weeding, harvesting, threshing. Farmers manure the fields using a composted mixture of human and animal excreta that is conserved in proper sinks and then distributed on the ground early spring. This practice provides plants with nutrients like nitrogen, phosphorus and potassium efficiently, and maintains soil functions and properties (Pelliciardi, 2012). Fields are also fed with ash from dung fires and minerals and salts coming from the irrigation water (Osmaston, 1994). Traditionally land preparation is performed with dzos (typical hybrids of yak and cow) to plough, before levelling and sowing the land by hand. Water for irrigation comes from glaciers through canals diverted into smaller arms that reach the fields. Water quantity and number of irrigation times during the growing season depend on different factors: kind of crop, soil, 
field topography and location, average evapotranspiration. At the beginning of the farming season, around April-May, local farmers hope for long warm sunny days (to melt ice), instead of wishing for cloudy weather like the agriculturists who live in regions watered by monsoon rain: "When glacier forms in $p h u$ [high altitude areas], ocean is formed in the lower parts; thundering cloud has no rain, the gossip girl has no wedding" (ancient folk proverb cited in Angchok \& Singh 2006). Harvesting goes from late August till the end of September. Animals are used for threshing by trampling in a circular platform near the farmer's house. The threshed crop is further treated to separate grain from straw, using air movement and wind. Finally, crops are put into sacks and stocked in the house store; straw and fodder are staked on the roof.

Figure 2 is a representation of the system through the energy system language (Odum, 1996). The system is supported by natural inputs that are consumed or withdrawn without being exhausted. Renewable resources, provided for free by the environment, are locally available according to contextual and peculiar conditions: for instance, this area is characterized by intense solar radiation and scarce precipitation. Meltwater from glaciers, exploited through an artificial channel system, plays a crucial role for irrigation (Labbal, 2007). Glaciers are remote and out of the farmers' control: their dependence on global climatic conditions makes the farming system dependent on exogenous factors. Each product generates grain and straw. Grain is consumed as a main component of the family diet; straw is used to feed the animals, together with fodder. Animals and the population are consumers, whose subsistence is assured by this flow of agroproducts. The small storages represent both the conservation of food reserves and the collection of human and animal excreta to be used as organic fertilizer. The system is also characterized by feedbacks. Products are recycled both directly as seeds and indirectly as animal and human labour and organic manure. The latter is important to regenerate the soil functions and create the condition for cultivation. Demenge (2007) states that "the [local] biocapacity is also to a large extent the product of human activities, [...] and Ladakhi farmers may create and expand biocapacity according to their needs". Furthermore, according to Dollfus \& Labbal (2009), "[cultivated] field [in central Ladakh] is the domesticated land par excellence". Part of the final product is stored for food security; a portion of the product, if it is produced in excess, can be sold. Money (dashed arrows) is also used to buy rice, fruit, tea, sugar and salt. 


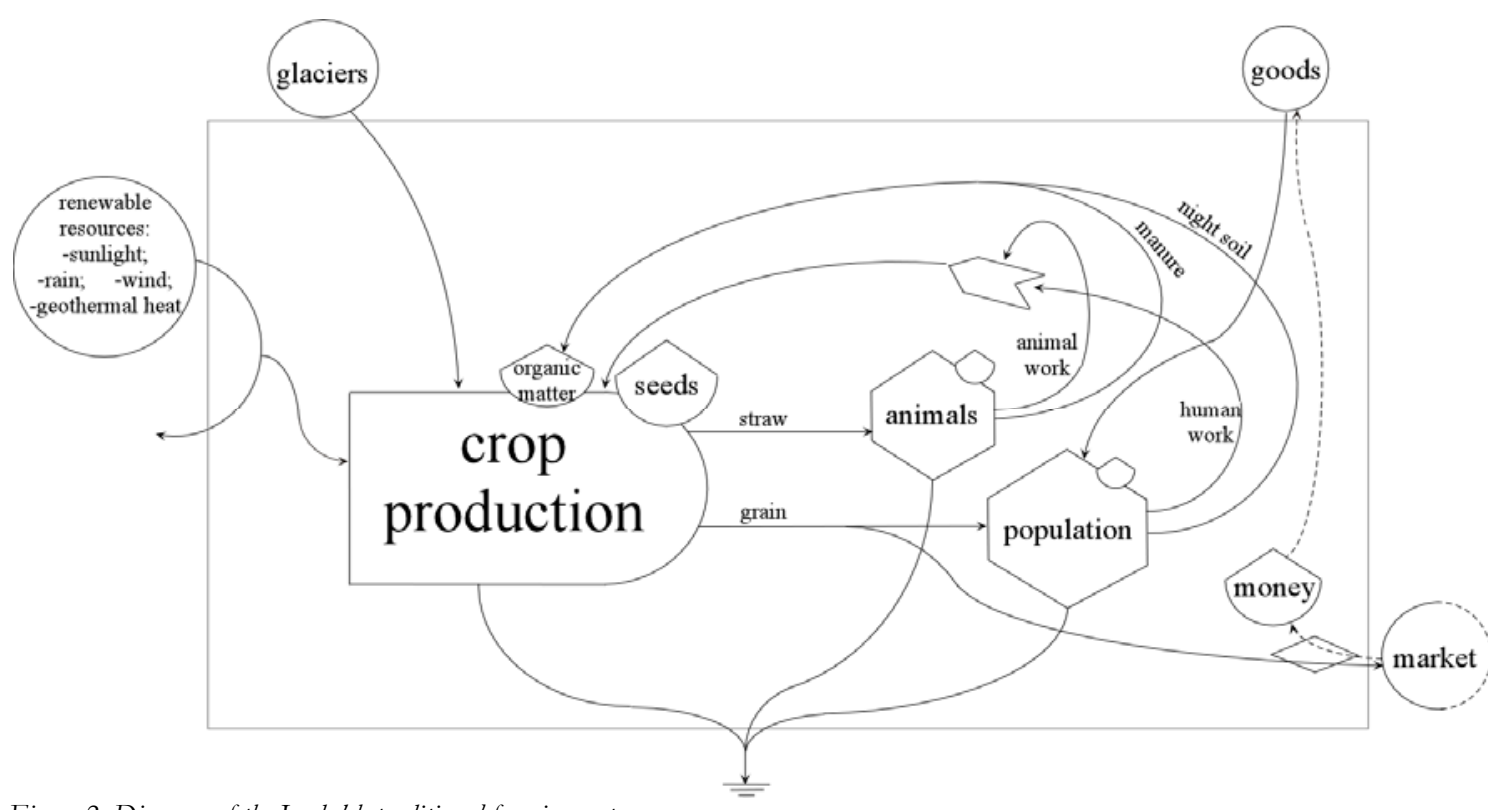

Figure 2. Diagram of the Ladakh traditional farming system.

According to the Agriculture Census 1995-96, there are 12,669 farms in the Leh District and the average land holding size is around 0.81 ha (LAHDC 2009). About $61.6 \%$ of the cultivators in Leh District belongs to the category "less than one hectare"; in the Indian Himalayan Region the percentage is $69.3 \%$ with 0.78 ha in Jammu \& Kashmir and 1.41 ha in India (Planning Commission 2010). The farm under study, located in Hemis Shukpachan, a village in the district of Leh, central Ladakh, includes six small fields (0.79 ha) cultivated by the family of the farmer ( 5 persons). The farmer owns six cattle, one donkey and sixteen sheep and goats, that during winter are stalled in the stable and fed with straw and fodder produced on the farm fields; this accommodation allows for the collection of composted excreta that will be used as organic fertilizer. Site-specific information has been collected during two missions to Ladakh in 2009 and 2010 (reference year), through direct measurement on the field, general observations, interviews at the Agriculture Department in Leh for general questions, and discussions with the farmer for specific questions. Inputs, calculations and references are listed in the Appendices A, B and C.

\subsection{Emergy Evaluation}

Energy drives all processes of nature (and human society), but it has been noted that different kinds of energy have different quality and ability to do work (Odum, 1971). To give a measure of this difference in energy quality, the concept of emergy has been introduced to express the quantity of "energy of one type required in transformations to generate a flow or storage" (Odum, 1988). Since solar energy is the fundamental energy for all biosphere processes, it is used as the common denominator to express all energy flows in a common unit. Emergy is therefore defined as the available solar energy used up, directly or indirectly, to make a service or a product (Odum, 1996), it is expressed in 
solar emergy joules (semj - see Campbell, 2012) and measures the convergence of energy flows in space and time into a product through the network of energy transformations. The factor that enables to express all kinds of energy in terms of solar equivalent is called Unit Emergy Value (UEV - emergy per unit, expressed in semj/J, semj/g or other unit). To quantify the emergy of a system or product, all the inputs to the system or production process must be quantified and converted into semj (equivalent solar energy) by means of suitable UEVs (Odum, 1996). Emergy evaluation thus determines the value of any resource on the basis of what is necessary for it to be produced. Approximately, the total emergy of a system (Emp) is given by the sum of the energy (or mass) content $\left(\mathrm{E}_{\mathrm{i}}\right)$ of the $\mathrm{i}^{\text {th }}$ input to the system multiplied by the corresponding $\mathrm{UEV}_{\mathrm{i}}$, as shown in Equation 1 (see Bastianoni et al. 2011, for a thorough analysis of this calculation method):

$$
E m_{P}=\left(E_{1} x U E V_{1}\right)+\left(E_{2} x U E V_{2}\right)+\ldots+\left(E_{n} x U E V_{n}\right)=\sum_{i=1}^{n} E_{i} x U E V_{i}
$$

(1)

In cases where the system has an output $\mathrm{P}$, its UEV is given by putting into relation the emergy of the system $\left(\mathrm{Em}_{\mathrm{P}}\right)$ and the energy content of the product $\left(\mathrm{E}_{\mathrm{P}}\right)$.

$U E V_{P}=\frac{E m_{P}}{E_{P}}$

(2)

The UEV depends on the specific production process; it embodies all the equivalent solar energy supporting, directly and indirectly, the process that generated the product.

Systematic and site-specific calculations of UEVs enable accurate quantitative representations of ecosystem and human effort in providing resources, goods and services. Moreover, the UEV is also a parameter able to give information on the efficiency of processes. For two processes that give the same product, the one with the lower UEV is the most efficient.

\section{Results}

In Table 1, the list of the inputs supporting the five agroproduction systems is presented. Input flows are quantified and expressed in $\mathrm{J} / \mathrm{yr}$ or $\mathrm{g} / \mathrm{yr}$, and then converted into emergy (expressed in semj/yr) by means of suitable UEVs. To avoid double counting, only the largest emergy input among sun, rain and wind has been considered, together with earth heat and meltwater. For the same reason, manure and labour are not considered as inputs because they are feedbacks within the system. The recycling of energy and matter, thanks to manure collection and management, makes organic matter systematically restored. Note that only the fields of barley and wheat are manured, but systematic crop rotation enables the positive effects of this practice to be diffused in every field. Labour is fed by the products of the farming system, and therefore is not an independent input. According to Abel (2004), "labour is mislabelled as a resource in the resource market [because] it is a product of ecosystems. People and animals can amplify 
the capture of available natural resources [...] which all life depends and economies are constructed".

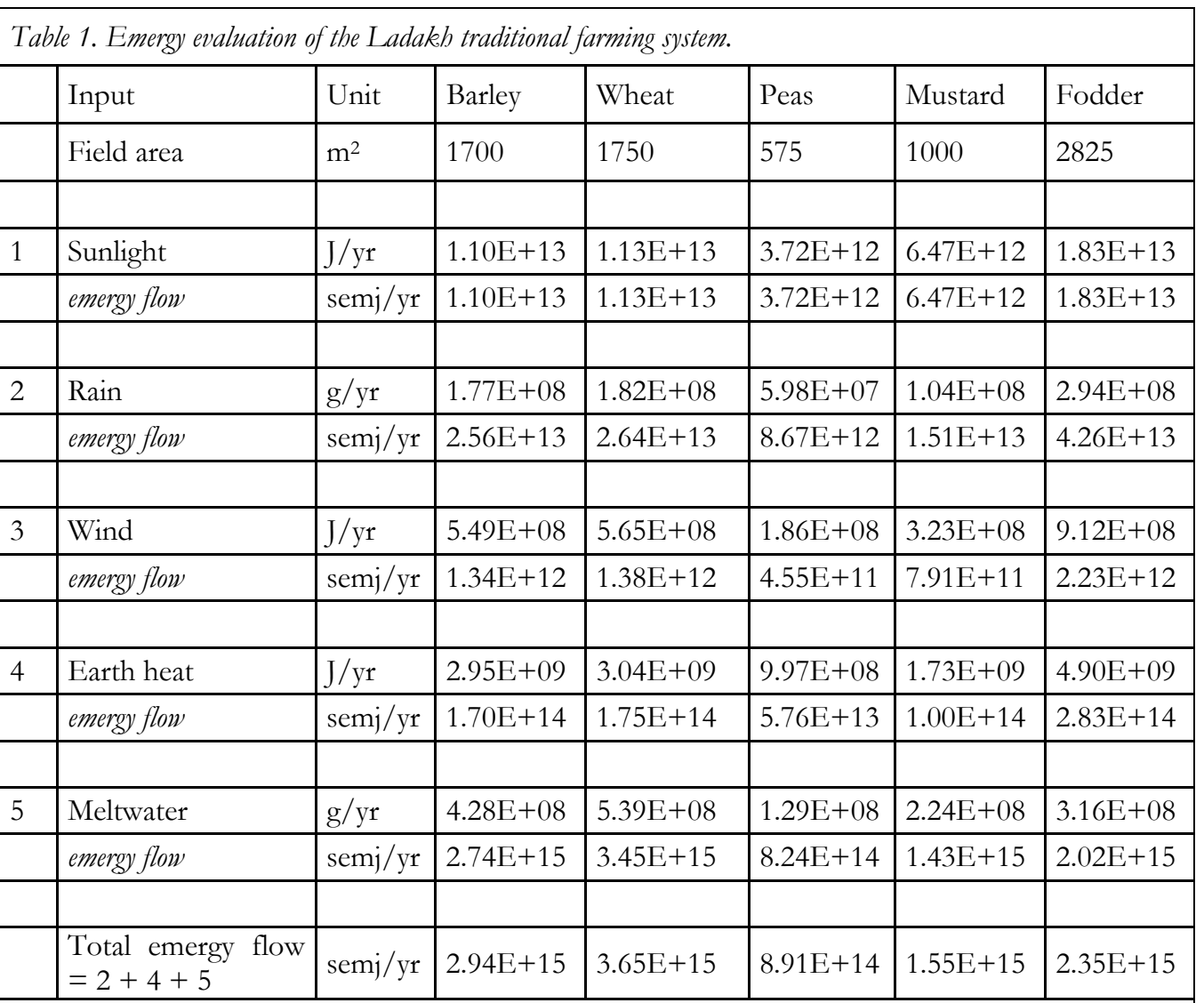

Baseline: $15.83 \times 10^{24} \mathrm{semj} / \mathrm{yr}$ (Odum et al., 2000); values and references for UEVs are: $1 \mathrm{semj} / \mathrm{J}$, for inputs $\mathrm{n}^{\circ} 1$ and $5.78 \mathrm{E}+04 \mathrm{semj} / \mathrm{J}$ for input $\mathrm{n}^{\circ} 4$ (Odum, 1996); $1.45 \mathrm{E}+05 \mathrm{semj} / \mathrm{g}$ for inputs $\mathrm{n}^{\circ} 2$ and $2.45 \mathrm{E}+03 \mathrm{semj} / \mathrm{J}$ for input $\mathrm{n}^{\circ} 3$ (Odum et al. 2000); $6.40 \mathrm{E}+06 \mathrm{semj} / \mathrm{g}$ for input $\mathrm{n}^{\circ} 5$ (Odum 2000).

For each field, the emergy flow has been calculated as the sum of the contribution of the independent inputs to the system: we considered the same annual contextual conditions (solar radiation, wind speed and direction, rainfall, geothermal heat, together with humidity, soil and land relief), and also computed data on different areas, water for irrigation, and organic manure. Among the emergy inputs, the largest is meltwater: its value is high because of the high UEV, i.e. the large amount of solar equivalent per unit product, corresponding to the high degree of concentration of solar energy over time. 
Table 2 presents the output of the activity.

Table 2. Agroproducts of the system.

\begin{tabular}{|l|l|l|l|l|l|l|}
\hline Output & Unit & Barley & Wheat & Peas & Mustard & Fodder \\
\hline \multirow{3}{*}{ Grain } & $\mathrm{g} / \mathrm{yr}$ & $3.41 \mathrm{E}+05$ & $3.41 \mathrm{E}+05$ & $4.80 \mathrm{E}+04$ & $8.00 \mathrm{E}+04$ & $0.00 \mathrm{E}+00$ \\
\cline { 2 - 8 } & $\mathrm{J} / \mathrm{yr}$ & $5.58 \mathrm{E}+09$ & $5.50 \mathrm{E}+09$ & $7.85 \mathrm{E}+08$ & $1.57 \mathrm{E}+09$ & $0.00 \mathrm{E}+00$ \\
\hline \multirow{3}{*}{ Straw } & $\mathrm{g} / \mathrm{yr}$ & $4.82 \mathrm{E}+05$ & $4.81 \mathrm{E}+05$ & $7.26 \mathrm{E}+04$ & $1.20 \mathrm{E}+05$ & $2.26 \mathrm{E}+06$ \\
\cline { 2 - 8 } & $\mathrm{J} / \mathrm{yr}$ & $7.79 \mathrm{E}+09$ & $7.55 \mathrm{E}+09$ & $1.14 \mathrm{E}+09$ & $1.89 \mathrm{E}+09$ & $4.10 \mathrm{E}+10$ \\
\hline
\end{tabular}

Products (except fodder) are classified as grain and straw, which have been considered co-products (the emergy of both is the same). Therefore, their UEVs have been calculated by dividing the total emergy flow (in semj/yr) by grain and straw, respectively, expressed in energy $\mathrm{J} / \mathrm{yr}$ ) and mass $(\mathrm{g} / \mathrm{yr})$ (see Table 3).

\begin{tabular}{|l|l|l|l|l|l|l|}
\hline Table 3. Unit Emergy V alues of crop productions. \\
\hline Output & Unit & Barley & Wheat & Peas & Mustard & Fodder \\
\hline \multirow{3}{*}{ Grain } & semj/g & $8.61 \mathrm{E}+09$ & $1.07 \mathrm{E}+10$ & $1.86 \mathrm{E}+10$ & $1.94 \mathrm{E}+10$ & $0.00 \mathrm{E}+00$ \\
\cline { 2 - 8 } & $\mathrm{semj} / \mathrm{J}$ & $5.27 \mathrm{E}+05$ & $6.64 \mathrm{E}+05$ & $1.13 \mathrm{E}+06$ & $9.87 \mathrm{E}+05$ & $0.00 \mathrm{E}+00$ \\
\hline \multirow{3}{*}{ Straw } & $\mathrm{semj} / \mathrm{g}$ & $6.09 \mathrm{E}+09$ & $7.60 \mathrm{E}+09$ & $1.23 \mathrm{E}+10$ & $1.29 \mathrm{E}+10$ & $1.04 \mathrm{E}+09$ \\
\cline { 2 - 8 } & $\mathrm{semj} / \mathrm{J}$ & $3.77 \mathrm{E}+05$ & $4.83 \mathrm{E}+05$ & $7.80 \mathrm{E}+05$ & $8.21 \mathrm{E}+05$ & $5.73 \mathrm{E}+04$ \\
\hline
\end{tabular}

\section{Discussion}

The UEVs of barley and wheat, $5.27 \mathrm{E}+05$ and $6.64 \mathrm{E}+05 \mathrm{semj} / \mathrm{J}$, respectively, are comparable to those of analogous products from conventional agricultural practices. For example, the UEV of corn (grain) produced in the USA, within a modern and mechanized farming system, is 7.37E $+05 \mathrm{semj} / \mathrm{J}$ (Brandt-Williams, 2002). In literature, the order of magnitude of the UEVs of wheat is $10^{5}$ to $10^{7}$ (Tilley et al. 2012); in Castellini et al. 2006, the UEV of barley $(4.21 \mathrm{E}+08 \mathrm{semj} / \mathrm{g})$ and Alfalfa fodder $(3.97+08 \mathrm{semj} / \mathrm{g})$ are reported. No UEV for pea and mustard have been found for comparisons.

Some of these values are slightly higher than those reported for the Ladakhi productions, due to the fact that, on one hand, only natural inputs, provided directly by the environment, are necessary to support the traditional Ladakhis farming system and, on the other hand, the fair management and recycling of energy and matter is adopted without producing residues or wastes (as in the case of western intensive agriculture). These factors limit the magnitude of emergy flow supporting the system. At the same time, according to data collected directly on the fields, the farmer had a normal production level in the 2010 season, with estimated yields of: $25.2 \mathrm{q} / \mathrm{ha}$ for barley, 24.4 $\mathrm{q} /$ ha for wheat, $12.5 \mathrm{q} / \mathrm{ha}$ for peas, $12.0 \mathrm{q} / \mathrm{ha}$ for mustard, and $80 \mathrm{q} / \mathrm{ha}$ for Alfalfa (personal communication). These values can be compared with crop yields in other areas: the world average is around $30.0 \mathrm{q} /$ ha for cereals (Dyson, 2001); in 2000 in India it was $23.4 \mathrm{q} / \mathrm{ha}$ (FAOSTAT, 2009); the average from 2001 to 2005 for wheat and barley in India was respectively $26.7 \mathrm{q} / \mathrm{ha}$ and $20.1 \mathrm{q} / \mathrm{ha}$; in Jammu \& Kashmir State, it was 
$16.9 \mathrm{q} / \mathrm{ha}$ and $6.4 \mathrm{q} / \mathrm{ha}$ (DAC, 2006). However, yields depend on a number of factors that can vary from place to place, and the comparison between values of mountain and plain agriculture is still under debate. Some Indian scientists (Singh, 1992; Kaul, 1998; Jodha et al. 1999) and Government officials ${ }^{1}$ from the plain consider the traditional local farming system backward and unproductive with very low yield potentialities ${ }^{2}$. On the other hand, the Leh Agriculture Department and other independent international researchers report better performances of the system (Demenge, 2007; Osmaston, 1994; Mankelow, 2003). Therefore, this system is designed in such a way that few inputs from the environment are converted into a above average quantity of agroproducts that are essential for supporting the population. Regarding the use of fertilizers, for example, Manjula (2007) states that "in spite of the established excellence of the traditional Ladakhi crop, official policy has taken for granted that it could be improved by the use of chemical fertilisers and the introduction of high yielding varieties of crops". However, local farmer community uses agricultural chemicals with caution (Sagwal, 1991), or in a mix with manure, at least in rural areas while near the town of Leh greater use of inorganic fertilizers has been reported (Manjula, 2007). Unfortunately, by attempting to transform agriculture into a more modern activity, the Leh District risks losing the ecosystem configuration of the traditional agroproduction system.

\subsection{Resource management}

The inputs to the traditional agricultural system are the natural resources provided for free by the environment. This kind of system has been able, for a very long time, to produce, select and recycle all the matter and energy necessary for the activity to be maintained continuously. In other words, it seems that local human activity has always been well integrated within the ecosystem dynamics, using resources without compromising their availability and closing cycles. Problems related to resource scarcity and unfertile soil have been tackled through careful management and social control, the latter meaning a fair distribution of environmental wealth (e.g. water and land). "Renewability" is the keyword of the Ladakhi attitude; at the same time, local nonrenewable natural capital is not systematically depleted (e.g. in the form of loss of soil functions). This is possible by virtue of a set of consolidated techniques: manure returning/recycling technology, area management through a system of manmade terraces, the use of straw and fodder to feed the animals, and negligible production and efficient disposal of wastes.

The fact that few inputs are used to generate agroproducts for people's subsistence implies that the vulnerability, as a lack of resource redundancy, of this system must also be taken into consideration. In fact, beyond the elements that characterize the typical

1 “The harsh environment and apparently simple subsistence agriculture in Zanskar [Ladakh province/block] have led most visitors and government officials to assume that the local crops are rather unproductive." (Osmaston, 1994).

2 J\&K Crop Production Statistics for the Year 1999-2000 to 2006-2007 reports average yield for wheat and barley in the Leh District at only $9.0 \mathrm{q} / \mathrm{ha}$ and $14.8 \mathrm{q} / \mathrm{ha}$; see also Krishi Vigyan Kendra, $6^{\text {th }}$ Scientific Advisory Committee Meeting Report, Leh 2006, "Area, Production and Productivity of major crops cultivated in the District", pg. 11, unpublished document. 
fragility of mountain societies (see UNDP-Agenda 21, 1992, Art. 13), the dependence on remote water sources, climatic events, but also population growth in certain areas and the transition of society towards modernization, may influence the delicate relationship between man and its environment. In brief, the system seems to be an example of compliance with the rules of sustainability, i.e. durability, respect of biophysical limits, preservation of relations among people and between the community and the environment, also expressed in terms of flows of energy and matter (see Pulselli et al. 2008).

\subsection{Key factors of local agroproduction}

Meltwater flow for irrigation and organic matter and nutrients in soil are the main limiting factors of the traditional farming activity. In this dry cold desert environment, meltwater from glaciers for irrigation is a critical concern for humans; water comes from a finite though large storage, whose exhaustion does not depend on withdrawal. According to Angchok \& Singh (2006), irrigation technology was introduced in the tenth century from neighbouring regions when the first canals were constructed. Water, flowing close to the village, is shortly diverted to irrigate fields and managed according to a traditional communal system that has been defined as a "fine-tuned mechanism for distributing water equitably and efficiently" (Gutschow, 1997). Global climate change may compromise water availability in the case of the reduction of Himalayan glaciers and changes in the snowfall patterns. For an overview of this debated question, see, for example, Armstrong (2010), Ganjoo et al. (2010), Kamp et al. (2011) and Thayyen \& Gergan (2010). In emergy terms, meltwater for irrigation is the largest input to the system. This also depends on its $\mathrm{UEV}$, equal to $6.40 \mathrm{E}+06 \mathrm{semj} / \mathrm{g}$ (Odum, 2000), that reflects the large quantity of solar energy that has been necessary, directly and indirectly, for the formation of glaciers. Moreover, due to the dimension of the source, meltwater can be considered a renewable resource, flow limited, whose use must be optimized, but the stock is seemingly far from exhaustion.

The induced soil fertility and functions (physical, biogeochemical and mechanical properties) is considered a product of this traditional farming system. In this harsh region, soil was first enriched and then maintained for centuries, by repeated additions of manure as a part of a continuous (re)cycling of all agricultural products. This practice compensates the loss of organic matter due to erosion and cultivation and the uptake of mineral nutrients by plants. Assessing the intrinsic value of soil would be of great importance for pursuing long-term sustainability; emergy evaluation can offer an alternative approach, because it "enumerates the value of soil based on the environmental work required to produce it" (Cohen et al. 2006). A measure of the value of agricultural soil is given by dividing the total emergy flow to the five fields by the energy embodied in manure conferred in the fields minus the energy loss due to top soil erosion and cultivation (see Table 4). This means that the total emergy flow that cycles year after year is the source of the slow accumulation of organic matter in soil, representative of its functions, that has increased from almost zero (centuries ago) to the current value. Formally: $\mathrm{UEV}_{\text {soil }}[\mathrm{semj} / \mathrm{J}]=$ total emergy $[\mathrm{semj} / \mathrm{yr}] /$ (energy conferred with manure - energy loss by erosion and cultivation) $\mathrm{J} / \mathrm{yr}]$. 
We use energy as a proxy of the creation and the consequent accumulation of soil fertility, consistent with the logic of cumulative energy typical of emergy. This net increase has the total emergy flowing through the system attached because it is a coproduct of the entire cycle.

\begin{tabular}{|l|l|l|l|}
\hline \multicolumn{4}{|l|}{ Table 4. Energy balance in soil and UEV calculation. } \\
\hline $\mathrm{a}$ & Total emergy flow (five fields) & $1.14 \mathrm{E}+16$ & $\mathrm{semj} / \mathrm{yr}$ \\
\hline $\mathrm{b}$ & Total cultivated area & 7850 & $\mathrm{~m}^{2}$ \\
\hline c & Area manured (barley and wheat only) & 3450 & $\mathrm{~m}^{2}$ \\
\hline $\mathrm{d}$ & Quantity of manure measured & 2725 & $\mathrm{~kg}$ \\
\hline $\mathrm{e}$ & Total energy contribution to soil functions by manure & $8.21 \mathrm{E}+08$ & $\mathrm{~J} / \mathrm{yr}$ \\
\hline $\mathrm{f}$ & Total energy lost from top soil erosion in cultivated area & $1.21 \mathrm{E}+08$ & $\mathrm{~J} / \mathrm{yr}$ \\
\hline $\mathrm{g}$ & Energy balance (= energy inflow - energy outflow) & $7.01 \mathrm{E}+08$ & $\mathrm{~J} / \mathrm{yr}$ \\
\hline & UEV of energy in soil as a proxy of soil functions $(=\mathrm{a} / \mathrm{g})$ & $1.62 \mathrm{E}+07$ & $\mathrm{semj} / \mathrm{J}$ \\
\hline
\end{tabular}

The result of this calculation $\left(1.62 \times 10^{7} \mathrm{semj} / \mathrm{J}\right)$ is a site-specific UEV of man-made agricultural fertile soil: it is the product of centuries of fair resource management aimed at concentrating and storing (indirect) solar energy into the ground. For this reason it is much higher than UEVs commonly used in the emergy assessment of agroproductions (see, for example, Brandt Williams, 2002).

\subsection{Continuity and Changes in Agricultural Practices}

A transition from traditional land-based economy to modernization has been occurring in Ladakh, and in particular in the Leh district. Under modernization and government development programs, farmers often adopt new technological adjustments. The contribution of machineries, fossil energy and chemical fertilizers is becoming more and more relevant, implying dependence on external resources and markets (Dame \& Nüsser, 2008). Some farmers prefer the easier application of the granular chemical fertilizers in bags than digging out, transporting and spreading organic manure; furthermore, raising animals is hard and time-consuming. However, other farmers are aware of the induced consequences on soil functions and capacity, as well as on food quality (Dame \& Mankelow, 2010). Traditional crop production is also discouraged by other emerging phenomena: the shortage of manpower due to the departure of young people to town, attracted by the new service economy; the distribution of government subsidized food-grain, carried by heavy lorries from the far-away Indian plain; changes in local diets, that are becoming more and more dependent on rice (Dame \& Nüsser, 2011). From an emergy viewpoint, these socio-economic transformations will result in a change in the structure of the system and in its inputs. This can be immediately represented in the diagram (Figure 2) by an increase in goods and services coming from outside the boundaries, namely machinery, chemical fertilizers, fossil fuels, and human labour, which will induce an overall rise in emergy flows. On the other hand, yields will probably increase in the short run, but decrease after few years (Mankelow, 2003) due to the progressive loss of ecosystem functions on which farming activity strongly depends, resulting in an increase in the environmental cost of agroproducts (UEVs). 


\section{Conclusions}

Ladakh traditional agriculture has always been focused on the production of food to support the population, and the continuous re-production of the conditions for long-term conservation of the whole system: in brief, it has been focused on sustainability. To evaluate the relationship between local traditional agricultural practices and the environment, emergy evaluation has been applied to a traditional familymanaged farming system in the Leh District. It has enabled us to identify and quantify the resources supporting the system and the environmental cost of the entire production process. The UEVs of agroproducts (environmental costs per unit product) have been calculated. The system under study shows high efficiency in energy transformation, no dependency on the economic system or other exogenous factors, and completely relies on local resources. This paper also presents a calculation of the high value of agricultural soil (in terms of its UEV), as a result of centuries of soil fertility management through recycling, manure technology, crop rotation, and resource use optimization. The influence of external markets and the emergence of socio-economic dynamics are progressively changing production and consumption habits, even in peripheral areas, determining population movement and increasing dependence on external resources. Sustainable development programs and policies, especially in mountain areas, must consider the interdependency of the local socio-cultural values, the environmental knowledge, and the limits of natural resources. In this sense, the Ladakh traditional agroproduction model should be encouraged to maintain a sustainable relationship with the environment, promote social welfare, and, ultimately, gain economic profits.

\section{Acknowledgements}

We would like to thank the farmer, Mr. Tsering Tondup Namgyal, the Agriculture Department in Leh, Mr. Gohlam Moamd. Bardi (Chief Agric. Office, Leh) and Mr. Thinles Dawa (Agriculture Extension Officer) for their help with investigations and data collection on the traditional and modern farming system in the Leh District.

\section{Appendix A. Notes to Table 1}

(1) Sunlight $=($ field area $) \mathrm{m}^{2} \bullet$ (average annual insolation $) \mathrm{J} / \mathrm{m}^{2} \mathrm{yr} \cdot(1$-albedo $)=\mathrm{J} / \mathrm{yr}$.

Annual average insolation $=7.80 \mathrm{E}+09 \mathrm{~J} / \mathrm{m}^{2} \mathrm{yr}$ (Jacobson, 2000); albedo 0.17 (bare soil Markvart \& Castążer, 2003).

(2) Rain $=\left(\right.$ field area) $\mathrm{m}^{2} \bullet$ (annual average rainfall) $\mathrm{m} / \mathrm{yr} \cdot 1 \mathrm{E}+06$ (water density) $\mathrm{g} / \mathrm{m}^{3}=\mathrm{g} / \mathrm{yr}$. Annual average rainfall $=0.104 \mathrm{~m} / \mathrm{yr}$ (Archer \& Fowler, 2004).

(3) Wind = (field area) $\mathrm{m}^{2} /$ (altitude) $\mathrm{m} \cdot$ (density of air) $1.23 \mathrm{~kg} / \mathrm{m}^{3} \cdot$ (average wind speed square) $(\mathrm{m} / \mathrm{s})^{2} \bullet$ (diffusion coefficient) $\mathrm{m}^{2} / \mathrm{s} \bullet$ (one year period in second) $(365 \cdot 24 \cdot 60 \bullet 60$ ) $\mathrm{s} / \mathrm{yr}=\mathrm{J} / \mathrm{yr}$. Altitude $=3650 \mathrm{~m}$ asl; average wind speed $=1.4 \mathrm{~m} / \mathrm{s}$ (Bansal \&Rijal (Eds), 2000); diffusion coefficient $=15.1 \mathrm{~m}^{2} / \mathrm{s}$ (Campbell, 1998).

(4) Earth heath $=$ (field area) $\mathrm{m}^{2} \bullet$ (heat flow) W/ $\mathrm{m}^{2} \bullet(365 \cdot 24 \cdot 60 \bullet 60)$ (one year period in second $)=\mathrm{J} / \mathrm{yr}$. Average heat flow $=0.055 \mathrm{~W} / \mathrm{m}^{2}$ (Hochstein \& Regenauer-Lieb, 1998).

(5) Meltwater $=$ (field area) $\mathrm{m}^{2} \cdot$ (height of water irrigation) $\mathrm{m} /$ day $\bullet$ (number of days for irrigation during one year cropping season) day $/ \mathrm{yr} \cdot 1 \mathrm{E}+06 \mathrm{~g} / \mathrm{m}^{3}$ (water density) $=\mathrm{g} / \mathrm{yr}$. Height of water diverted into field calculated through the volume measured during one day irrigation $=$ 
$0.028 \mathrm{~m} /$ day (personal measure); number of days for irrigation during one year cropping season: 9, 11, 8, 8, 4 day/yr respectively for barley, wheat, peas, mustard, and fodder (farmer communication).

\section{Appendix B. Notes to Table 2 and 3}

Grain quantities yielded is taken from farmer communication. Quantity utilized = (quantity yielded per year minus quantity for sowing in the next year for each field) $\mathrm{g} / \mathrm{yr}$.

Energy content $=$ (quantity) $\mathrm{g} / \mathrm{yr} \bullet$ (energy contents) $\mathrm{kcal} / \mathrm{g} \bullet 4186 \mathrm{~J} / \mathrm{kcal}=\mathrm{J} / \mathrm{yr}$.

Energy contents are 3906, 3853, 3908, 4685 - E-03 kcal/g respectively for barley, wheat, peas, mustard.

Straw quantities $=[(1$ - harvest index $) /$ harvest index $] \cdot$ Grain quantities mass $=\mathrm{g} / \mathrm{yr}$.

Harvest index $=0.47$ for barley and wheat, 0.50 for peas and mustard (Osmaston, 1994).

Energy contents $=$ (quantity) $\mathrm{g} / \mathrm{yr} \bullet($ energy contents) $\mathrm{kcal} / \mathrm{g} \bullet 4186 \mathrm{~J} / \mathrm{kcal}=\mathrm{J} / \mathrm{yr}$.

Energy contents are 3859, 3754, 3754, 3754 - E-03 kcal/g respectively for barley, wheat, peas, mustard.

Fodder quantity yielded is taken from farmer communication.

Energy content $=$ (quantity) $\mathrm{g} / \mathrm{yr} \bullet$ (energy contents) $\mathrm{kcal} / \mathrm{g} \bullet 4186 \mathrm{~J} / \mathrm{kcal}=\mathrm{J} / \mathrm{yr}$.

Energy contents $4335 \bullet \mathrm{E}-03 \mathrm{kcal} / \mathrm{g}$.

Source for all energy contents: INEA, http://alimenti.vet.unibo.it/item.asp $\bullet$ id=C-01-02 (Accessed 24/09/10)

\section{Appendix C. Notes to Table 4}

Quantity of manure has been measured on site. Energy content in manure E $=72 \mathrm{kcal} / \mathrm{kg}$ (Gezer et al. 2003). Total energy contribution to soil by manure = (quantity of manure) $\mathrm{kg} \cdot$ (energy content in manure) $\mathrm{kcal} / \mathrm{kg} \cdot 4186 \mathrm{~J} / \mathrm{kcal}=\mathrm{J} / \mathrm{yr}$. Total energy lost from top soil erosion in cultivated area $=$ Energy loss $=6.8 \mathrm{E}+03 \mathrm{~g} / \mathrm{ha} / \mathrm{yr}$ (org. mat. loss) $\bullet 5 \mathrm{kcal} / \mathrm{g}$ (energy content, Odum, 1996) $\bullet 4186 \mathrm{~J} / \mathrm{kcal}=1.42 \mathrm{E}+08 \mathrm{~J} / \mathrm{ha} / \mathrm{yr}$. Loss of organic matter $=\mathrm{m}^{2}($ field area $) \cdot 100$ $\mathrm{g} / \mathrm{m}^{2} \mathrm{yr}$ (mass of topsoil loss) 0.0068 (organic matter content) $=6.8 \mathrm{E}+03 \mathrm{~g} / \mathrm{yr}$. Erosion rates $=$ 1.0 tonnes/ha yr (Geneletti \& Dawa, 2009) equal to $100 \mathrm{~g} / \mathrm{m}^{2} \mathrm{yr}$; average of organic matter content in soil $0.68 \%$ (Sagwal, 1991).

\section{References}

Abel T, 2004. Systems diagrams for visualizing macroeconomics. Ecological Modelling. 178:189-194.

Agostinho F, Diniz G, Siche R, Ortega E, 2008. The use of emergy assessment and the geographical information system in the diagnosis of small family farms in Brazil. Ecological Modelling. 210:3757.

Alfaro-Arguello R, Diemont SAW, Ferguson BG, Martin JF, Nahed-Toral J, Álvarez-Solís JD, Ruíz RP, 2010. Steps toward sustainable ranching: An emergy evaluation of conventional and holistic management in Chiapas, Mexico. Agricultural Systems. 103:639-646.

Archer DR, Fowler HJ, 2004. Spatial and temporal variations in precipitation in the Upper Indus basin, global teleconnections and hydrological implications. Hydrology and Earth System Sciences. $8(1): 47-61$.

Armstrong RL, 2010. The glaciers of the Hindu Kush-Himalayan region: A summary of the science regarding glacier melt/retreat in the Himalayan, Hindu Kush, Karakoram, Pamir, and Tien Shan mountain ranges. ICIMOD, Kathmandu.

Angchok D, Singh P, 2006. Traditional irrigation and water distribution system in Ladakh. Indian Journal of traditional Knowledge. 5(3):397-402. 
Bansal NK, Rijal K. (Eds), 2000. Profiting from Sunshine. Passive Solar Building in the Mountains. ICIMOD, Kathmandu.

Bastianoni S, Morandi F, Flaminio T, Pulselli RM, Tiezzi EBP, 2011. Emergy and emergy algebra explained by means of ingenuous set theory. Ecological Modelling. 222(16):2903-2907.

Brandt-Williams SL, 2002. Emergy of Florida agriculture. Folio 4 (2nd printing). In: Handbook of Emergy Evaluation. Center for Environmental Policy, Environmental Engineering Science. University of Florida, Gainesville, Florida.

Brown MT, Herendeen RA, 1996. Embodied energy analysis and emergy analysis: a comparative view. Ecological Economics. 19:219-235.

Campbell DE, 1998. Emergy analysis of human carrying capacity and regional sustainability: an example using the State of Maine. Environmental Monitoring Assessment. 51:531-569.

Campbell DE, Garmestani AS, 2012. An energy systems view of sustainability: Emergy evaluation of the San Luis Basin, Colorado. Journal of Environmental Management. 95:72- 97.

Castellini C, Bastianoni S, Granai C, Dal Bosco A, Brunetti M, 2006. Sustainability of poultry production using the emergy approach: Comparison of conventional and organic rearing systems. Agriculture, Ecosystems and Environment. 114: 343-350.

Cavalett O, Ferraz de Queiroz J, Ortega E, 2006. Emergy assessment of integrated production systems of grains, pig and fish in small farms in the South Brazil. Ecological Modelling. 193:205-224.

Cohen MJ, Brown MT, Shepherd KD, 2006. Estimating the environmental costs of soil erosion at multiple scales in Kenya using emergy synthesis. Agriculture, Ecosystems and Environment. 114, 249-269.

Comar V, Tilley D, Felix E, Turdera M, Neto M C, 2004. Comparative eMergy evaluation of Castorbean (RICINUSCOMMUNIS) production systems in Brazil an USA. In Ortega E, Ulgiati S, editors: Proceedings of IV Biennial International Workshop “Advances in Energy Studies". Unicamp, Campinas, SP, Brazil. pp. 227-237.

Cuadra M, Björklund J, 2007. Assessment of economic and ecological carrying capacity of agricultural crops in Nicaragua. Ecological Indicators. 7(1):133-149.

DAC (Department of Agriculture and Cooperation), 2006. State-wise Normal Area, Production and Yield of Wheat, Average of 2001-02 to 2005-06. Department of Agriculture and Cooperation, Directorate of Economic \& Statistic. http://dacnet.nic.in/eands/APY_Normal Estimates.htm. Accessed $\underline{05 / 03 / 2010 .}$.

Diemont SAW, Martin JF, 2009. Lacandon Maya ecosystem management: sustainable design for subsistence and environmental restoration. Ecological Applications. 19(1): 254-266.

Dame J, Mankelow JS, 2010. Stongde Revisited: Land-use Change in Central Zangskar. Erdkunde. 64(4):355370.

Dame J, Nüsser M, 2008. Development Paths and Perspectives in Ladakh, India. Geographische Rundschau. 4(4):20-27.

Dame J, Nüsser M, 2011. Food Security in High Mountain Regions: Agricultural Production and the Impact of Food Subsidies in Ladakh, Northern India. Food Security. 3(2):179-194.

Demenge J, 2007. Measuring Ecological Footprints of Subsistence Farmer in Ladakh. Paper presented at International Ecological Footprint Conference, Cardiff, Wales (UK). http://web.mnstate.edu/robertsb/307/ANTH\%20307/ecologicalfootprintfarmersladakh.PDF. Accessed 26/05/2009.

Dyson T, 2001. World Food Trends: A Neo-Malthusian Prospect?. Proceedings of the American Philosophical Society. 145(4): 438-455.

Dollfus P, Labbal V, 2009. Ladakhi landscape units. In: Smadja J, (Eds.). Reading Himalayan Landscapes over Time. Environmental Perception, Knowledge and Practice in Nepal and Ladakh. Collection Sciences Sociales 14, xiv, French Institute of Pondicherry, India. pp. 85-106.

FAO (Food and Agriculture Organisation), 2008. Conservation and Adaptive Management of Globally Important Agricultural Heritage Systems (GIAHS), Terminal Report. www.fao.org/fileadmin/templates/giahs/PDF/GIAHS B terminalReport.pdf. Accessed $02 / 03 / 2011$.

FAO. Statistical Yearbook 2009. Vol. 4.

http://www.fao.org/docrep/014/am079m/am079m00.htm. Accessed 25/10/2011

Ganjoo RK, Koul MN, 2009. Is the Siachen glacier melting? Current Science. 97(3),309-310. 
Geneletti D, Dawa D, 2009. Environmental impact assessment of mountain tourism in developing regions: A study in Ladakh, Indian Himalaya. Environmental Impact Assessment Review. 29:229-242.

Gezer I, Acaroglu M, Haciseferogullari H, 2003. Use of energy and labour in apricot agriculture in Turkey. Biomass and Bioenergy. 24:215 - 219.

Gutschow K, 1997. Lords of the fort, lords of the water, and no lords at all. The Politics of Irrigation in Three Tibetan Societies. In: Recent Research on Ladakh 'Proceedings of the $6^{\text {th }}$ International Colloquium on Ladakh, Leh, 1993' International Association of Ladakh Studies. Motilal Banarsidass Publishers Limited, Delhi.

Haden A C, 2002. Emergy analysis of food production at S\&S homestead farm. S\&S Center for Sustainable Agriculture, Lopez Island, WA, USA.

http://sshomestead.org/userfiles/file/emergy\%20analysis.pdf. Accessed 10/02/2010.

Hau LH, Bakshi RB, 2004. Promise and problems of emergy analysis. Ecological Modelling. 178:215-225.

Hochstein MP, Regenauer-Lieb K, 1998. Heat generation associated with collision of two plates: the Himalayan geothermal belt. Journal of Volcanology and Geothermal Research. 83(1-2):75-92.

Humbert-Droz B, Dawa S, 2004. Eds. Biodiversity of Ladakh: Strategy and Action Plan. Sampark, New Delhi.

Jodha NS, Sharma P, Richard C, Tulachan P, 1999. Development Strategies for Agriculture and relate sectors in Ladakh. ICIMOD, Kathmandu.

Jacobson A, 2000. Solar energy measurements for Ladakh, India. Proceeding of the $24^{\text {th }}$ National Renewable Energy Convention 2000 of the Solar Energy Society of India, Mumbai. http://users.humboldt.edu/arne/Ladakh_solar data NREC2000.pdf. Accessed 25/08/2010.

Kamp U, Byrne M, Bolch T, 2011. Glacier Fluctuations between 1975 and 2008 in the Greater Himalaya Range of Zanskar, Southern Ladakh. Journal Mountain Sciences. 8:374-389.

Kaul HN, 1998. Rediscovery Of Ladakh. Indus Publishing Company, Delhi.

Labbal V, 2007. Interpréter les « dysfonctionnements » des systèmes irrigués traditionnels. L'exemple d'une oasis du Ladakh central (Himalaya indien). Techniques \& Culture. 48-49:125-148.

LAHDC, 2009. Statistical Hand Book 2008/09. Statistics and Evaluation Office, Leh.

Lefroy E, Rydberg T, 2003. Emergy evaluation of three cropping systems in south western Australia. Ecological Modelling. 161:195-211.

Lu H, Campbell D, Chen J, Qin P, Ren H, 2009. Emergy and economic evaluations of four fruit production systems on reclaimed wetlands surrounding the Pearl River Estuary, China. Ecological Engineering. 35:1743-1757.

Manjula B. 2007. Thoray, Planning for a people centred future. Kharu Block Development Report. Jamsetji Tata Trust, Mumbai, India.

Mankelow JS, 1999. The Introduction of Modern Chemical Fertilisers to the Zanskar Valley Ladakh and its Effects on Agricultural Productivity, Soil Quality and Zanskari Society. Dissertation in Environmental Science and Anthropology. Oxford Brookes University.

Mankelow JS, 2003. The Implementation of the Watershed Development Programme in Zangskar, Ladakh: Irrigation Development, Politics and Society. Dissertation for the degree of MA South Asian Area Studies of the School of Oriental and African Studies (University of London).

Markvart T, CastaLżer L, 2003. Practical Handbook of Photovoltaics: Fundamentals and Applications. Elsevier Ltd, Oxford.

Martin JF, Diemont SAW, Powell E, Stanton M, Levy-Tacher S, 2006. Emergy evaluation of the performance and sustainability of three agricultural systems with different scales and management (USA, Mexico). Agricultural, Ecosystem Environment.115:128-140.

Negi SS, 2002. Cold desert of India. Indus Publishing Company, New Delhi.

Odum HT, 1971. Environment, Power and Society. John Wiley, New York.

Odum HT, 1988. Self organization, transformity and information. Science. 242: 1132-1139.

Odum HT, 1996. Environmental accounting. Emergy and environmental decision making. John Wiley \& Sons, New York.

Odum HT, 2000. Emergy of global Processes. Handbook of Emergy Evaluation: Folio \#2, A compendium of data for emergy computation issued in a series of folios. Center for Environmental Policy, Univ. of Florida, Gainesville. 
Odum HT, Brown MT, Brandt-Williams SL, 2000. Introduction and Global Budget, Folio \#1. Handbook of Emergy Evaluation. Center for Environmental Policy, Environmental Engineering Sciences, University of Florida, Gainesville.

Osmaston H, 1994. The Farming System. In: Crook J, Osmaston H, (Eds.). Himalayan Buddhist Villages. Motilal Banarsidass Publishers. Delhi. pp. 139-198.

Pelliciardi V, 2010. Tourism traffic volumes in Leh district: an overview. International Association for Ladakh Studies, Ladakh Studies. 26:14-23.

Pelliciardi V, 2012. Nutrient (N, P, and K) recycling in traditional soil fertility practices in Leh district: a case study at small farm level. Ladakh Studies 28: 27-35.

Planning Commission (Government of India). 2010. Report of the Task Force. http://planningcommission.nic.in/aboutus/taskforce/task hill1009.pdf,

accessed 20/05/2011.

Pulselli FM, Bastianoni S, Marchettini N, Tiezzi E, 2008. The Road to Sustainability: GDP and Future Generations. WIT Press, Southampton, UK.

Rizvi J, 1996. Ladakh, Crossroads of High Asia. 2th ed. Oxford India Paperbacks -Oxford University Press, New Delhi.

Rodney CL, 1952. Self-Sufficiency on the Farm. In: Agricultural History. 26(2):37-41 Published by: Agricultural History Society Stable.

http://www.jstor.org/stable/3740085. Accessed 15/03/2011.

Sabharwal A, Singh A, 2005. Working Paper $n^{\circ} 1$ : Agriculture \& Agribusiness. Center for Development of Corporate Citizenship S. P. Jain Institute of Management \& Research Mumbai; In: Enterprising Ladakh, Prosperity, Youth Enterprise and Cultural Values in Peripheral Regions, LAHDC, Leh.

Sagwal SS, 1991. Ladakh, Ecology and Environment. Ashish Publishing House, New Delhi.

Singh H, 1992. Ecological Set-Up and Agrarian Structure of High Altitude Villages of Ladakh. In: Singh RB editor. Dynamics of Mountain Geo-Systems. 204-221.

Thayyen RJ, Gergan JT, 2010. Role of glaciers in watershed hydrology: a preliminary study of a Himalayan catchment. The Cryosphere. 4:115-128.

Tilley, D.R., Agostinho, F., Campbell, E., Ingwersen, W., Lomas, P., Winfrey, B., Zucaro, A., and Zhang. P., 2012. The ISAER transformity database. International Society for Advancement of Emergy Research. www.emergydatabase.org. Accessed 28/03/2012.

U.N.D.P., 1992. Managing fragile ecosystems: Sustainable Mountain Development. Agenda 21, Chapter 13. N.Y..

Verma LR, 1998. Indigenous technology knowledge for watershed management in upper north-west Himalayas of India.

http://www.fao.org/docrep/x5672e/x5672e00.htm\#Contents. Accessed 10/05/2009.

$\mathrm{Xi}$ YG, Qin P, 2009. Emergy evaluation of organic rice-duck mutualism system (China). Ecological Engineering. 3(5):1677-1683.

Zhang LX, Yang ZF, Chen GQ, 2007. Emergy analysis of cropping-grazing system in Inner Mongolia Autonomous Region, China. Energy Policy. 35:3843-3855. 